The Cyclical Behavior of Bank Capital Buffers in an Emerging Economy: Size Does Matter

Por:

Andrés Felipe García-Suaza Borradores de ECONONÁA José E. Gómez-González Andrés Murcia Pabón Fernando Tenjo-Galarza
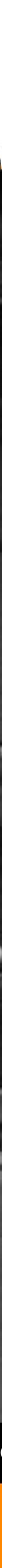


\title{
The Cyclical Behavior of Bank Capital Buffers in an Emerging Economy: Size Does Matter ${ }^{1}$
}

\author{
Andrés Felipe García-Suaza ${ }^{2} \quad$ José E. Gómez-González ${ }^{34}$ \\ Andrés Murcia Pabón ${ }^{5} \quad$ Fernando Tenjo-Galarza ${ }^{6}$
}

October 26, 2011

\footnotetext{
${ }^{1}$ Disclaimer: The findings, recommendations, interpretations and conclusions expressed in this paper are those of the authors and not necessarily reflect the view of the Banco de la Republica or its Board of Directors, or the Department of Economics of the Universidad del Rosario.

${ }^{2}$ Assistant Professor, Economics Department, Universidad del Rosario. Calle 14 \# 4-69, Bogotá, Colombia. E-mail address: andres.garcia@urosario.edu.co

${ }^{3}$ Corresponding author

${ }^{4}$ Senior Research Economist, Banco de la República (Central Bank of Colombia). Carrera 7 \# 14-78 Piso 11, Bogotá, Colombia. E-mail address: jgomezgo@banrep.gov.co

${ }^{5}$ Senior Economist, Monetary and Reserves Affairs Office, Banco de la República (Central Bank of Colombia). Carrera 7 \# 14-78 Piso 4, Bogotá, Colombia. E-mail address: amurcipa@banrep.gov.co

${ }^{6}$ Member of the Board of Governors, Banco de la República (Central Bank of Colombia). Carrera 7 \# 14-78 Piso 6, Bogotá, Colombia. E-mail address: ftenjoga@banrep.gov.co
} 


\begin{abstract}
Using a panel of Colombian banks and quarterly data between 1996:1 and 2010:3, we study the relationship between short-run adjustments in bank capital buffers and the business cycle. We follow a partial adjustment framework and control for several variables that have been identified as important determinants of bank capital buffers in previous studies, and find that bank capital buffers vary over the business cycle. We are able to identify a negative co-movement of capital buffers and the business cycle. However, we also find that capital buffers of small and large banks behave asymmetrically during the business cycle. While the former appear to be constant over time, once the appropriate set of control variables is used, the latter present a countercyclical behavior. Our results suggest the possible need of the implementation of regulatory policy measures in developing countries.
\end{abstract}

JEL Classification: C26; G21; G28.

Keywords: Bank capital buffers; Credit risk; Regulation; Colombia 


\section{Introduction}

Studying the time-series behavior of banks' capital buffers is important for at least two fundamental reasons. First, capital requirements have become one of the main instruments of today's banking regulation. Following the Basel accord, financial institutions' supervisors around the world follow closely the capital ratio of the institutions they regulate and impose minimum requirements. Arguably the main objective of Basel II is to create a closer liaison between banks' risk taking and individual capital requirements. In order to promote a sound asset and liability management, the current regulatory framework pretends to stimulate banks to hold an adequate level of capital which corresponds to their risk-taking decisions. Clearly, appropriate capital levels vary during the business cycle. There is ample evidence showing that the probabilities of observing counterparty credit rating downgrades and defaults is quite different during economic expansions and during cyclical downturns (see, for instance, Kavvathas (2000), and Gómez-González and Hinojosa (2010)). During an economic upturn firms and households perform well and are less prone to committing default on their debt obligations than during an economic downturn. Thus, the amount of bank capital required to cover against unexpected losses depends on the state of the business cycle. Given that capital is costly, it will not be optimal for banks to hold a constant level of capital across time, and thus observed capital buffers should fluctuate during the business cycle. Second, the literature on capital crunch shows that under capital regulations the capitalization ratio is important for financial institutions when they are taking decisions on portfolio composition (see Peek and Rosengren (1995), and Estrella et al (2000)). Particularly interesting, as shown by Van den Heuvel (2009), bank capital regulations might have an effect on bank lending and on the response of lending to monetary policy actions in a dynamic setting. If the market for bank equity is imperfect, banks cannot readily issue new equity at all moments in time ${ }^{1}$. Therefore, in the presence of minimum capital requirements, banks forgo profitable lending opportunities to reduce the probability of falling below the regulatory minimum levels in the future in case credit risk materializes. There are

\footnotetext{
${ }^{1}$ There is ample theoretical (see. for instance, Myers and Majluf (1984), and Stein (1998)) and empirical support (Cornett and Tehranian, and Calomiris and Hubbard (1995)) for the assumption that issuing new equity can be costly, and that the cost might depend on banks' individual characteristics.
} 
explicit as well as implicits costs for falling below the minimum capital requirement. Explicit costs depend on the particular regulatory design of the country in which the bank operates and relate to penalties and restrictions imposed by the supervisor. Implicit costs deal with the effect of the penalization of a bank on its depositors' behavior.

Bank capital buffers are defined as the excess capital maintained by financial institutions at a given point in time. If capital markets were perfect, the optimal capital buffer will be set to zero for all banks, because it would be inefficient to maintain idle capital which is more costly to hold than insured deposits. However, in the presence of imperfect equity markets, capital can not be raised without cost. Therefore, it might be optimal for financial institutions to hold positive capital buffers.

Banks will hold different levels of capital depending on their individual characteristics, such as their access to equity markets, the levels of risk they assume, and their size, and also on the stage of the business cycle. The decisions they take on the amount of capital they withhold affect lending, and thus the transmission of monetary policy to the economy.

The dependence of capital buffers on the business cycle may have a negative impact on macroeconomic stability. Empirical studies have shown that banks' capital buffers of Western European banks fluctuate countercyclically over the business cycle (Ayuso et al. (2004), Lindquist (2004), Jopikii and Milne (2008), and Stolz and Wedow (2011)). Banks undertake a riskier behavior during times of economic expansion, expanding their loan portfolio without building up their capital buffers accordingly. In a bust, when banks observe the materialization of credit risk, those poorly capitalized will face the possibility of falling below the minimum required levels. Therefore, they will have to either issue new equity or increase their capital buffers reducing lending. Given that raising capital is specially hard during economic downturns when capital is scarse and costly, many banks have to cut lending in a considerable proportion. The resulting reduction in loanable funds experimented by firms and households amplifies the magnitude of the economic recession.

In this paper we study the behavior of Colombian banks' capital buffers during the business cycle. Our objective is to test whether capital buffers behave countercyclically, and whether individual characteristics of the banks influence their time-series behavior. We call the attention that the business cycle may affect 
banks' capital buffers both due to supply-side effects and through demand-side effects. In order to overcome this spicification issue, we follow Stolz and Wedow (2011) and test for asymmetries with respect to the capitalization of banks. Thus, we specify a partial adjustment model in which capital buffers this period depend on last period capital buffers, on the business cycle, and on other variables controlling for heterogeneity in the risk-behavior of banks.

Using quarterly balance sheet information on the universe of Colombian banks for the period 1996:1 - 2010:3, we show that capital buffers vary over the business cycle. However, the behavior of capital buffers across banks is heterogeneous: big banks' buffers are more responsive to the business cycle. In particular, we find that while large banks' capital buffers behave countercyclically, there is no statistical evidence that smaller banks' capital buffers change over time. We also find that increases in the ratio of total loans over assets has an asymmetric effect on capital buffers depnding on banks' size. While the effect of an increase in lending as a proportion of total assets is positive on the capital buffers of large banks, the effect is negative on small banks' capital buffers. This interesting result may be evidence of the short-sightedness of small banks who do not increase their safety margins when they are assuming higher risks while expanding credit. On the contrary, large banks appear to increase their capital buffers to hedge against possible negative shocks that can lead to credit risk materialization when loans are growing fast. Similarly, we find that while increases in the real growth rate of loans has a negative impact on capital buffers for small banks, it has a positive though not statistically significant - effect on large banks' buffers. Finally, we find that a prudential regulation introduced in 2007 by the Colombian financial system supervisor, that consisted in establishing a new system for managing credit risk in Colombian financial institutions (SARC), has had no significant effect in the time-series behavior of banks' capital buffers, although it might have had an effect in the level of buffers of small banks.

This study contributes to the literature on the behavior of capital buffers in several ways. First, up to our knowledge this is the first paper on the topic that provides evidence for banks of an emerging economy. The existing literature has focused on the behavior of banks' buffers in Western European economies. Therefore, our study allows the comparison of results for an emerging economy with those of developed European economies. Second, Colombia is a bank-based economy. More than $60 \%$ of non-financial firms' external funds are provided by banks. 
In that sense, the behavior of bank lending influences importantly firms' performance and investment behavior. Our results can be compared to those of Stolz and Wedow (2011), who study the case of banks in Germany, a developed bankbased economy. Third, we have a rich data set comprised of quarterly balance sheet information for over 15 years of all commercial banks in Colombia. Other related studies use yearly data, shorter time-periods, or only a sample of the existing banks. In that sense, our study has informational advantages over previous studies. Credit cycles in Colombia have been very pronounced. During the years 1998 - 2000 Colombia experienced a major banking crisis which led to changes in the concentration of the banking industry and to structural changes in the behavior of banks toward risk. Therefore, with our data set we are able to test for the effects of the banking crisis on banks' selection of capital buffers. In contrast, during 2004 - 2008 Colombia's banking system experimented an extraordinary period of credit expansion. For instance, in the years 2006 and 2007 the annual real growth rate of loans exceeded 30\%. Credit expansion was so rapid and pronounced that the financial system's authorities had to impose regulatory measures such as marginal reserve requirements.

Finally, our results suggest that capital buffers of banks with better access to equity markets tend to vary more over the business cycle. Specifically, security buffers of large banks with priviledged access to capital markets behave countercyclically, and this may have negative impacts on macroeconomic stability. An interesting implication of this finding is that if capital markets develop in such a way that smaller banks gain more access to them, it will be possible to expect that capital buffers of these banks will react more vigorously to the stage of the business cycle. From a macro-prudential policy perspective, this would suggest that regulation measures should be undertaken to incentive banks to behave in a less procyclical way. For instance, regulatory capital meausres that take into account this aspect could be implemented, particularly in emerging economies in which capital markets are developing at a rapid pace.

The structure of this paper is as follows: Section 2 presents the empirical model, Section 3 analyzes the data, Section 4 presents the results and robustness checks, and Section 5 concludes. 


\section{The empirical model}

Our objective is to test whether bank capital buffers change over the business cycle or not. In order to do so, we follow the methodology proposed by Ayuso et al. (2004) and Estrella (2004), who study the cyclical behavior of capital buffers of banks in Spain and the United States. We use a partial adjustment framework in which bank $i$ seeks to attain its optimal capital buffer, $B U F_{i, t}^{*}$, given its observed capital buffer at time $t-1$ is $B U F_{i, t-1}$ :

$$
\Delta B U F_{i, t}=\lambda\left(B U F_{i, t}^{*}-B U F_{i, t-1}\right)+\varepsilon_{i, t} \quad i=1, \ldots, N ; t=1, \ldots, T
$$

where $\lambda$ represents the speed of adjustment of the observed capital buffer towards its optimum level, $\triangle B U F_{i, t}=B U F_{i, t}-B U F_{i, t-1}$, and $\varepsilon_{i, t}$ is the error term.

Even though the optimal capital buffer of bank $i$ is unobservable, following Jopikii and Milne (2008) and Stolz and Wedow (2011) it is sensible to assume it depends on the stage of the business cycle due to its effect on credit risk and bank-specific variables. Adding $B U F_{i, t-1}$ to both sides of equation (1), we obtain the following expression:

$$
\begin{aligned}
\Delta B U F_{i, t}+B U F_{i, t-1} & =\lambda\left(B U F_{i, t}^{*}-B U F_{i, t-1}\right)+B U F_{i, t-1}+\varepsilon_{i, t} \\
B U F_{i, t} & =\lambda B U F_{i, t}^{*}+(1-\lambda) B U F_{i, t-1}+\varepsilon_{i, t} \\
B U F_{i, t} & =\lambda B U F_{i, t}^{*}+\gamma B U F_{i, t-1}+\varepsilon_{i, t} \quad i=1, \ldots, N ; t=1, \ldots, T
\end{aligned}
$$

where $\gamma=(1-\lambda)$. Following the argument above, we instrument the target capital buffer in terms of observables such as the business cycle, credit risk variables, ans bank-specific variables. Our empirical specification is given by equation (3) :

$$
B U F_{i, t}=\beta_{0}+(1-\lambda) B U F_{i, t-1}+X_{i, t}^{\prime} \theta+\varepsilon_{i, t}
$$

where $X_{i, t}$ is a vector of control variables that includes the annual GDP growth rate $(G D P)$, profitability of equity $(R O E)$, the ratio of non-performing loans to total loans $(R I S K)$, the real growth rate of loans $(D L O A N)$, and the loan to asset ratio $(L O A N S)$. Additionally we included two dummy variables; one controls for bank size (DUMMYSIZE), separating large banks from small banks, and 
the other one control for the inclusion of SARC in 2007 (DUMMYSARC). We define $\varepsilon_{i, t}=\alpha_{i}+u_{i t}$, where $\alpha_{i}$ is an idiosincratic component which we assume uncorrelated with the regressors contained in vector $X_{i, t}$, and $u_{i t}$ is a white-noise disturbance term.

All of the variables in equation (3) are defined in levels. Following conventional wisdom in panel data analysis, we proceed to transform equation (3) into first differences in order to obtain unbiased estimates.

Our main interest relies in the sign of the parameter associated with the variable $G D P$. The existing empirical literature suggests this sign is negative, indicating that capital buffers behave countercyclically (see, for instance, Stolz and Wedow (2011)). A negative impact of the business cycle variable on the change in capital buffers will indicate that during expansions, when banks are expanding credit, capital buffers fall; while during economic contractions capital buffers increase. This behavior has been called in the literature "banks short-sightedness" (Borio et al. (2001)). We test for this hypothesis for the whole universe of banks, and we test the same hypothesis separating banks according to their size characteristics. Particularly, we run separate regressions for small banks and for large banks. The intuition behind performing separate estimations according to bank size is that large institutions are less exposed to risk because they can diversify their assets more, because they can achieve economies of scale, or because they likely have been in business longer (Gómez-González and Kiefer, 2009). Thus, we expect a stronger effect of the business cycle variable on capital buffers for large banks than for small institutions.

Note that equation (3) specifies a dynamical structure in a panel data context. For that reason, we employ the dynamic panel data GMM estimator proposed by Blundell and Bond (1998). This estimation method generalized the method proposed by Arellano and Bond (1991), avoidind the weak instruments problem², and controlling for specific components in the error term.

\section{Data description}

We count with a rich data set, provided by the Superintendencia Financiera de Colombia, which contains quarterly data with balance sheet information on the

\footnotetext{
${ }^{2}$ The weak instruments problem appears in models with endogenous regressors in which using too many instruments may result is biased estimates of the parameters of interest.
} 
whole universe of Colombian banks for the period 1996:1 - 2010:3. Using this information we construct the variables mentioned above. It is important to mention that we define $B U F_{i, t}$ as the difference between the observed capital ratio of bank $i$ in period $t$ and $9 \%$, which is the regulatory level of minimum capital in Colombia $^{3}$. Figure 1 shows the time-series behavior of bank capital buffers and GDP. It can be seen that apparently capital buffers behave countercyclically. In fact, the Spearman correlation coefficient between capital buffers and GDP is of -0.61 . Figure 2 shows the behavior of capital buffers over time, discriminating by bank size. It is noticeable that after the banking crisis of the late 1990s small banks increased their capital buffers significantly more than large banks. This can be explained by differences in risk aversion of banks of different sizes and characteristics.

Figure 1: Capital buffers and GDP

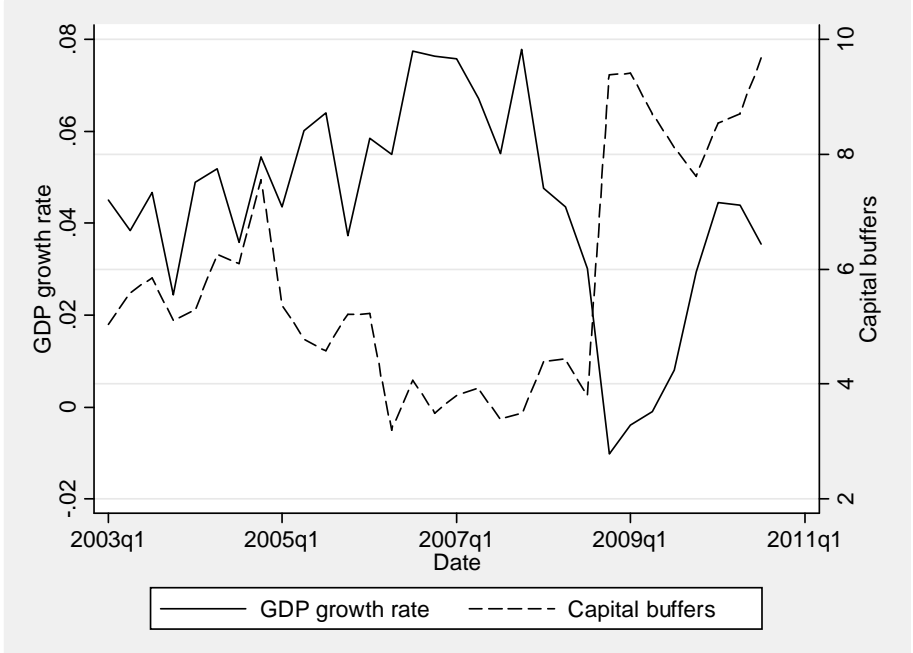

\footnotetext{
${ }^{3}$ If a bank falls below that capital level it is directly intervened by the Superintendencia Financiera de Colombia, the supervisor of Colombia's financial institutions.
} 
Figure 2: Capital buffers and bank size

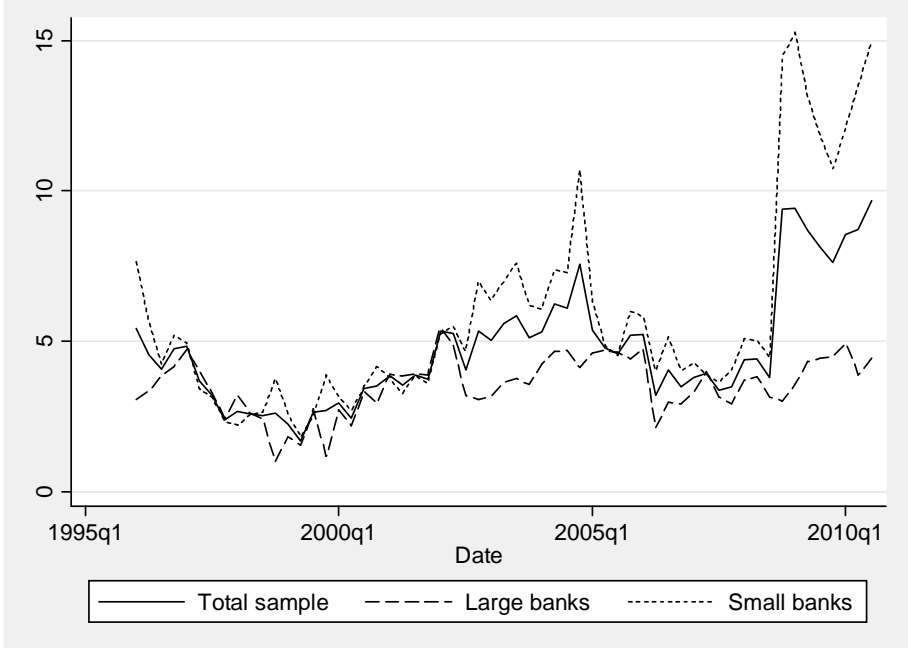

The control variables also vary significantly over the business cycle. In particular, the average $R O E$ for the whole sample of banks exhibits negative levels during the peiod of economic downturn and positive levels during the period of economic expansion, as expected. However, its behavior is heterogeneous depending on bank size. For large banks, the average $R O E$ is always positive, although it presents quite different levels during moments of expansion and moments of contraction. It is also important to note that the growth rate of loans of large banks during periods of economic upturn $(21.9 \%)$ is much higher than that of small banks (12.7\%). With respect to $R I S K$, both small and large banks register a higher indicator during bad times than during good times, as expected, although both types of banks do not appear to show very different behaviors. Finally, the share of loans out of total assets remains relatively constant during the sample period for both types of banks (see Tables $(1 a),(1 b)$, and $(1 c)$ ).

Note there is a change in the level of buffers in 2008, especially for small banks.

This change responds to the implementation of SARC and, particularly, to a decision taken by Colombia's financial system supervisor of suggesting a higher level of capitalization to a group of banks at the end of 2008. This change in the level of buffers generates a possible unit-root problem in the series of capital buffers. That is one of the reasons that led us to model the first difference of the series instead of its level. Below we show that the estimation results for the whole sample period do not change significantly when data from 2008:4 on is not considered for the regressions. We also show that the introduction of SARC led to a change in 
the level of small banks' capital buffers, but did not change the time-series behavior of their first differences.

Table 1a: Average value of regressos by sub-period. Whole sample

\begin{tabular}{ccccc}
\hline Period & ROE & RISK & DLOAN & LOANS \\
\hline $\mathbf{1 9 9 6 - 1 9 9 9}$ & -0.011 & 0.067 & 0.188 & 0.663 \\
$\mathbf{2 0 0 0 - 2 0 0 3}$ & -0.056 & 0.076 & 0.001 & 0.611 \\
$\mathbf{2 0 0 4 - 2 0 0 8}$ & 0.193 & 0.045 & 0.169 & 0.610 \\
$\mathbf{2 0 0 9 - 2 0 1 0}$ & 0.127 & 0.047 & 0.067 & 0.629 \\
\hline
\end{tabular}

Table 1b: Average value of regressos by sub-period. Large banks

\begin{tabular}{ccccc}
\hline Period & ROE & RISK & DLOAN & LOANS \\
\hline $\mathbf{1 9 9 6 - 1 9 9 9}$ & 0.106 & 0.068 & 0.128 & 0.653 \\
$\mathbf{2 0 0 0 - 2 0 0 3}$ & 0.023 & 0.089 & -0.027 & 0.568 \\
$\mathbf{2 0 0 4 - 2 0 0 8}$ & 0.251 & 0.043 & 0.219 & 0.576 \\
$\mathbf{2 0 0 9 - 2 0 1 0}$ & 0.228 & 0.043 & 0.068 & 0.602 \\
\hline
\end{tabular}

Table 1c: Average value of regressos by sub-period. Small banks

\begin{tabular}{ccccc}
\hline Period & ROE & RISK & DLOAN & LOANS \\
\hline $\mathbf{1 9 9 6 - 1 9 9 9}$ & -0.107 & 0.067 & 0.237 & 0.670 \\
$\mathbf{2 0 0 0 - 2 0 0 3}$ & -0.119 & 0.066 & 0.024 & 0.646 \\
$\mathbf{2 0 0 4 - 2 0 0 8}$ & 0.145 & 0.047 & 0.127 & 0.639 \\
$\mathbf{2 0 0 9 - 2 0 1 0}$ & 0.026 & 0.051 & 0.066 & 0.656 \\
\hline
\end{tabular}

\section{Estimation results}

In this section we present the results of estimating equation (4), and we account for the asymmetric behavior of capital buffers of small and large banks over the business cycle. Table 2 shows the estimation results, following the Blundell Bond (1998) two-step system GMM method, for the capital buffers of Colombian banks for the whole sample period (1996:3 - 2010:1). The first column shows the results obtained when grouping together all banks, while the second and third columns show the results when considering separately large banks and small banks, respectively. We performed separate estimations for small and large banks due to 
theoretical expectations and due to the fact that the variable associated to bank size resulted negative and statistically significant in the estimation of the whole sample of banks. We included four lags of the dependent variable in the set of regressors given that we count with quarterly data and considering information criteria. For similar reasons we included the fourth lag of the business cycle variable $(G D P)$ as a regressor.

The sign of GDP is always negative as expected, indicating that capital buffers behave countercyclically. However, this variable is statistically different from zero only for large banks at conventional levels of significance. This quite interesting result is similar to the one obtained by Jopikki and Milne $(2008)^{4}$, who find that capital buffers behave countercyclically for large banks in countries of the EU15. However, while they find that capital buffers of small banks behave prociclically, we do not find such behavior in Colombian small banks. Our results suggest that capital buffers of small banks in Colombia do not vary over the business cycle. If both types of banks have the same access to equity markets, and these markets do not work efficiently, this heterogeneous behavior of capital buffers will suggest that large banks are more prone to exacerbate business cycle fluctuations in Colombia than smaller banks. If obtaining capital is equally hard for small and large banks, those banks that lower their capital buffers during periods of economic expansion are assuming higher risks and will be more likely to fall below the level of regulatory capital during economic downturns when credit risk materializes, having to cut lending in order to avoid regulatory penalties. However, if small and large banks have differential access to equity markets (see for instance Holmström and Tirole (1997)), the reason for observing a heterogeneos behavior of capital buffers over the business cycle might be a different one. If large banks have better access to equity markets than small banks, as it is the case in Colom$\mathrm{bia}^{5}$, the former can lower their capital buffers during economic expansions without incurring in major risks, while the latter do not have that possibility. Smaller banks find it more costly to re-build their capital stocks, and thus their optimal

\footnotetext{
${ }^{4}$ Stolz and Wedow (2011), and other studies, have also found evidence of a countercyclical behavior of bank capital buffers for Western European economies. Unfortunately, those papers have not tested for a heterogeneous behavior of capital buffers over the business cycle depending on bank size.

${ }^{5}$ Private capital markets in Colombia are highly underdeveloped, as it is the case in most emerging economies. Only a few number of firms issue equity regularly, due to the difficulties of finding demand for equity at a reasonable price. These firms (financial and non-financial) are large, traditional Colombian firms.
} 
capital buffer is less responsive to short-run variations of economic conditions. The fact that large banks' capital buffers present a negative co-movement with the business cycle may have an interesting implication for the transmission of monetary policy. If during busts the materialization of credit risk leads to a reduction of these banks' capital buffers to an extend in which they approach the minimum regulatory level, these banks will have to either raise additional capital or cut lending. Reducing lending leads to an increase in the capital ratio through the immediate reduction in risk-weighted assets. Equity capital is relatively costly in relation to debt because the payments on debt-interest receive tax deductions and because equity carries the most risk since it has no claim to the company's assets. Therefore, banks tend to cut lending under this situation, amplifying the business cycle. The transmission of monetary policy is therefore potentially asymmetric depending on the bahavior of banks' capital buffers over the business cycle. The signs of the coefficients related to DLOANS and LOANS provide additional support to our story. The signs of both DLOANS and LOANS is negative and statistically significant for small banks, showing that capital buffers reduce for these banks when they increase lending. This result is obtained after controlling for variables related to risk-taking decisions $(R I S K)$, and is completely different to the result obtained for large banks, for which the sign of $L O A N S$ is positive and the effect of $D L O A N S$ on the capital buffers is statistically equal to zero. Therefore, our findings suggest that small banks encounter difficulties when trying to increase their capital buffers due to limited access to equity markets ${ }^{6}$.

The variable $D U M M Y S A R C$ is statistically equal to zero in all three specifications. Therefore, aparently the introduction of SARC in 2007 did not influence the behavior of the change in banks' capital buffers in Colombia. As shown in figures 1 and 2, the introduction of SARC, and more specificaly the decision taken by Colombia's financial system supervisor of suggesting a higher level of capitalization to a group of banks at the end of 2008, had a one-time (level) impact on small banks' capital ratios. However, this regulation did not seem to change the behavior of capital buffers over time.

Important to note, under all three specifications we cannot reject the null hypoth-

\footnotetext{
${ }^{6}$ In a first instance, the fact that both $D L O A N S$ and $L O A N S$ excerpt a negative influence over $B U F$ could indicate either a riskier behavior of small banks or a lower access of these banks to capital markets, relative to the access of large banks. However, after controlling for covariates proxying for risk-taking behavior, the fact that both signs are negative can be interpreted as evidence of a limited access to capital markets by small banks in Colombia.
} 
esis that overidentifying restrictions are valid (Sargan test). Thus, there is evidence that valid instruments are being used.

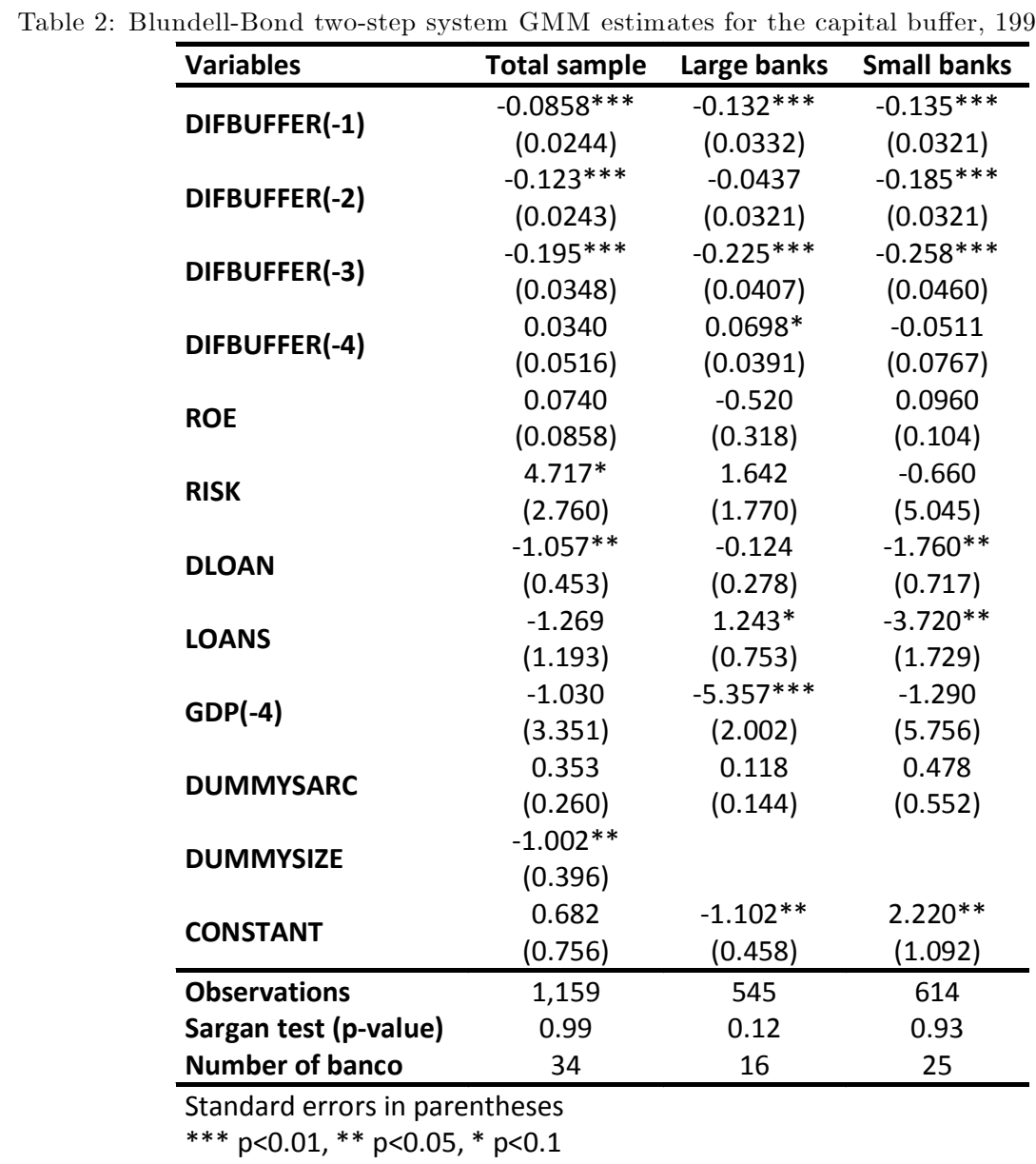

As mentioned above, there was a change in the level of small banks' capital ratios at the end of 2008. As a robustness check of our results, we performed the same estimations but we reduced our sample period, eliminating all observations after 2008:3. Table 3 presents the results of performing Blundell Bond (1998) two-step system GMM estimations of the behavior of capital buffers for the constrained sample period. Notice that the results are qualitatively identical to those reported in Table 2 and interpreted above. The magnitudes of the estimated coefficients are also very similar, and again under all three specifications we cannot reject the null hypothesis that overidentifying restrictions are valid (Sargan test). 
Table 3: Blundell-Bond two-step system GMM estimates for the capital buffer, 1996:1 - 2008:3

\begin{tabular}{|c|c|c|c|}
\hline Variables & Total sample & Large banks & Small banks \\
\hline DIFBUFFER(-1) & $\begin{array}{c}-0.0858^{\star \star *} \\
(0.0261)\end{array}$ & $\begin{array}{c}-0.134^{\star \star \star} \\
(0.0358)\end{array}$ & $\begin{array}{c}-0.136^{\star \star \star} \\
(0.0341)\end{array}$ \\
\hline DIFBUFFER(-2) & $\begin{array}{c}-0.123^{\star \star \star} \\
(0.0259)\end{array}$ & $\begin{array}{l}-0.0437 \\
(0.0347)\end{array}$ & $\begin{array}{l}-0.187^{\star \star \star} \\
(0.0341)\end{array}$ \\
\hline DIFBUFFER(-3) & $\begin{array}{l}-0.199^{* * *} \\
(0.0372)\end{array}$ & $\begin{array}{l}-0.221^{* * *} \\
(0.0442)\end{array}$ & $\begin{array}{l}-0.267^{\star * *} \\
(0.0489)\end{array}$ \\
\hline DIFBUFFER(-4) & $\begin{array}{c}0.0369 \\
(0.0563)\end{array}$ & $\begin{array}{l}0.0735^{\star} \\
(0.0423)\end{array}$ & $\begin{array}{l}-0.0618 \\
(0.0838)\end{array}$ \\
\hline ROE & $\begin{array}{c}0.0799 \\
(0.0907)\end{array}$ & $\begin{array}{l}-0.492 \\
(0.345)\end{array}$ & $\begin{array}{l}0.0967 \\
(0.109)\end{array}$ \\
\hline RISK & $\begin{array}{c}4.712 \\
(3.090)\end{array}$ & $\begin{array}{c}1.619 \\
(1.944)\end{array}$ & $\begin{array}{l}-2.128 \\
(5.602)\end{array}$ \\
\hline DLOAN & $\begin{array}{c}-1.113^{* *} \\
(0.490)\end{array}$ & $\begin{array}{l}-0.102 \\
(0.299)\end{array}$ & $\begin{array}{c}-2.052^{\star * *} \\
(0.771)\end{array}$ \\
\hline LOANS & $\begin{array}{l}-1.640 \\
(1.402)\end{array}$ & $\begin{array}{c}1.285 \\
(0.854)\end{array}$ & $\begin{array}{c}-4.446^{\star *} \\
(1.947)\end{array}$ \\
\hline GDP(-4) & $\begin{array}{l}-2.096 \\
(4.102)\end{array}$ & $\begin{array}{l}-5.954^{\star \star} \\
(2.467)\end{array}$ & $\begin{array}{l}-3.111 \\
(6.662)\end{array}$ \\
\hline DUMMYSARC & $\begin{array}{c}0.536 \\
(0.428)\end{array}$ & $\begin{array}{l}0.0524 \\
(0.233)\end{array}$ & $\begin{array}{c}0.888 \\
(0.780)\end{array}$ \\
\hline DUMMYSIZE & $\begin{array}{l}-1.054^{* *} \\
(0.495)\end{array}$ & & \\
\hline CONSTANT & $\begin{array}{c}0.964 \\
(0.886)\end{array}$ & $\begin{array}{c}-1.115^{\star \star} \\
(0.528)\end{array}$ & $\begin{array}{l}2.828^{* *} \\
(1.242)\end{array}$ \\
\hline Observations & 1,023 & 474 & 549 \\
\hline Sargan test (p-value) & 0.99 & 0.07 & 0.91 \\
\hline Number of banco & 32 & 15 & 23 \\
\hline
\end{tabular}

\section{Concluding remarks}

Using a panel of Colombian banks and data between 1996:1 and 2010:3, we study the relationship between short-run adjustements in bank capital buffers and the business cycle. We follow a partial adjustment framework and control for several variables that have been identified as important determinants of bank capital buffers in previous studies, and find that bank capital buffers vary over the business cycle. We are able to identify a negative co-movement of capital buffers and and the business cycle. However, we also find that capital buffers of small and large banks behave asymmetrically during the business cycle. While the former appear to be constant over time, once the appropriate set of control variables is used, the latter present a countercyclical behavior. 
We also find that while when small banks increase lending their capital buffers reduce. Meanwhile, increases in lending do not appear to affect large banks' capital buffers. Given we are controlling for banks' risk-taking decisions, we interpret our results as showing that optimally small and large banks behave differently due to the differential access they have to equity markets. Large banks, with better access to capital markets, lower their capital buffers during economic expansions without incurring in major risks while seeking to take advantage of profitable lending opportunities. Small banks find it more costly to re-build their capital stocks due to limited access to equity markets, and thus their optimal capital buffer is less responsive to short-run variations on economic conditions. Our findings suggest that a change in prudential regulation implemented by Colombia's financial system supervisor in 2007 has had no impact on the behavior of banks' capital buffers over time. The decision taken by the supervisor of suggesting a higher level of capitalization to a group of banks at the end of 2008 had a onetime (level) impact on small banks' capital ratios but did not seem to change the dynamic behavior of capital buffers.

Finally, our results suggest that capital buffers of banks with better access to equity markets tend to vary more over the business cycle. Specifically, security buffers of large banks with priviledged access to capital markets behave countercyclically, and this may have negative impacts on macroeconomic stability. An interesting implication of this finding is that if capital markets develop in such a way that smaller banks gain more access to them, it will be possible to expect that capital buffers of these banks will react more vigorously to the stage of the business cycle. From a macro-prudential policy perspective, this would suggest that regulation measures should be undertaken to incentive banks to behave in a less procyclical way. For instance, regulatory capital meausres that take into account this aspect could be implemented, particularly in emerging economies in which capital markets are developing at a rapid pace.

\section{References}

Arellano, M. and S. Bond (1991): "Some tests of specification for panel data: Monte carlo evidence and application to employment equations", Review of Economic Studies 58, 277 - 297. 
Ayuso, J.; D. Pérez, and J. Saurina (2004): "Are capital buffers pro-cyclical? Evidence from Spanish panel data", Journal of Financial Intermediation 13, 249 264.

Blundell, R. and S. Bond (1998): "Initial conditions and moment restrictions in dynamic panel data models", Journal of Econometrics 87, 115 - 143.

Borio, C.; C. Furfine, and P. Lowe (2001): "Prociclicality of the financial system and financial stability: issues and policy options", Bank for International Settlements Working Paper No. 1. Available at: http://www.bis.org/publ/bppdf/bispap01a.pdf

Calomiris, C. W. and R. G. Hubbard (1995): "Internal finance and investment: evidence from the undistributed profits tax of 1936-37", Journal of Business 68, $443-482$.

Estrella, A.; S. Park, and S. Peristiani (2000): "Capital ratios as predictors of bank failure", Economic Policy Review 6, 33 - 52.

Gómez-González, J.E. and I.P.O Hinojosa (2010): "Estimation of conditional time-homogeneous credit quality transition matrices", Economic Modelling 27, $89-96$.

Gómez-González, J.E. and N.M. Kiefer (2009): "Bank failure: evidence from the Colombian financial system", International Journal of Business and Finance research $2,15-32$.

Holström, B. and J. Tirole (1997): "Financial Intermediation, Loanable Funds, and Real Sector", Quarterly Journal of Economics 112, 663 - 692.

Jopikii, T. and A. Milne (2008): The cyclical behavior of European bank capital buffers", Journal of Banking and Finance 32, 1440 - 1451.

Kavvathas, D. (2000): "Estimating credit rating transition probabilities for corporate bonds", AFA 2001 New orleans Meetings. Available at: http://papers.ssrn.com/sol3/papers.cfm?abstract_id $=252517$

Lindquist, K. (2004): "Banks' buffer capital: how important is risk?", Journal of International Money and Finance 23, 493 - 513. 
Myers, S. and N. Majluf (1984): "Corporate financing and investment decisions when firms have information that investors do not", Journal of Financial Economics $13,187-222$.

Peek, J. and E.S. Rosengren (1995): "Bank regulation and the credit crunch", Journal of Banking and Finance 19, 679 - 692.

Stein, J. C. (1998): "An adverse selection model of bank asset and liability management with implications for the transmission of monetary policy", RAND Journal of Economics 29, 466 - 486.

Stolz, S. and M. Wedow (2011): "Banks' regulatory capital buffer and the business cycle: evidence for Germany", Journal of Financial Stability 7, 98 - 110.

Van den Heuvel, S.J. (2009): "The bank capital channel of monetary policy", Mimeo. Available at: http://www.dallasfed.org/news/research/2009/09macro_heuvel.pdf 